\title{
Effects of Dichrostachys cinerea (1.) Wight \& Arn (Fabaceae) on herbaceous species in a semi-arid rangeland in Zimbabwe
}

\author{
Clarice Mudzengi', Shakkie Kativu², Everson Dahwa', \\ Xavier Poshiwa ${ }^{3}$, Chrispen Murungweni ${ }^{4}$
}

I Department of Research and Specialist Services, Makoholi Research Institute P. Bag 9182, Masvingo, Zimbabwe 2 Department of Biological Sciences, University of Zimbabwe, P. Box MP 167, Mt Pleasant, Harare, Zimbabwe 3 Department of Animal Science, University of Zimbabwe, P. O. Box MP 167, Mt Pleasant, Harare, Zimbabwe 4 Chinhoyi University of Technology, Department of Animal Production and Technology, P. Bag 7724, Chinhoyi, Zimbabwe

Corresponding author: Clarice Mudzengi (clarice.mudzengi@gmail.com)

Academic editor: Dirk Schmeller | Received 6 April 2014 | Accepted 17 July 2014 | Published 8 August 2014

http://zoobank.org/F51AE39F-A58D-43C8-834B-392F90C14702

Citation: Mudzengi CP, Kativu S, Dahwa E, Poshiwa X, Murungweni C (2014) Effects of Dichrostachys cinerea (1.) Wight $\&$ Arn (Fabaceae) on herbaceous species in a semi-arid rangeland in Zimbabwe. Nature Conservation 7: 51-60. doi: $10.3897 /$ natureconservation.7.5264

\begin{abstract}
Anthropogenic alteration of an environment and other disturbance regimes may enable the expansion of some native species into new geographical areas, a phenomenon observed with Dichrostachys cinerea. Five $D$. cinerea invaded sites, each approximately one hectare in size were assessed for the effects of $D$. cinerea on native herbaceous species diversity, richness, basal cover, litter cover, top hamper and plant vigour. The same attributes were studied in five uninvaded sites adjacent to, and equal in size to each invaded site. Forty herbaceous species were identified in the area. There were significant differences $(\mathrm{P}<0.05)$ noted in species richness, basal cover, litter cover, top hamper, plant vigour, and species diversities between invaded and uninvaded sites, with uninvaded sites recording higher values than invaded sites. Altitude, erosion and the edaphic variables $\mathrm{pH}, \mathrm{N}, \mathrm{P}$ and $\mathrm{K}$, which were included as explanatory variables, also differed significantly $(\mathrm{P}<0.05)$ between invaded and uninvaded sites. Of the $30 \mathrm{D}$. cinerea invaded plots established for herbaceous species assessments, 26 were positively correlated with altitude, erosion, $\mathrm{pH}, \mathrm{P}, \mathrm{N}$ and $\mathrm{K}$. It is imperative to find ways of managing $D$. cinerea in order to reduce its adverse effects on herbaceous species.
\end{abstract}

Copyright Clarice Mudzengi et al. This is an open access article distributed under the terms of the Creative Commons Attribution License (CC BY 4.0), which permits unrestricted use, distribution, and reproduction in any medium, provided the original author and source are credited. 


\section{Keywords}

Dichrostachys cinerea, herbaceous species, invasion

\section{Introduction}

Ecologically unsustainable anthropogenic activities such as agriculture, mining, and oil exploration, coupled with climate change and variability, facilitate plant species invasions. This is exacerbated by increases in the frequency and extent of natural disturbances such as droughts, hail storms, fire, insect outbreaks and disease in boreal forests which upset ecological and economic balances, perpetrating invasions (IPCC 2007). The Convention on Biodiversity (CBD) targeted 'to achieve by 2010 a significant reduction of the current rate of biodiversity loss at the global, regional, and national level as a contribution to poverty alleviation, and to the benefit of all life on Earth' (SCBD 2010). This facilitated development of policies to preserve biodiversity including elimination or control of alien invasive species. Most of the studies on plant species invasion ecology focus on these alien invasives, yet the control of exotic and native species by the same ecological processes may explain the positive correlation often found between exotic and native species richness (Lonsdale 1999).

Dichrostachys cinerea is a deciduous low thorny tree or shrub that produces bicoloured fragrant flowers. It is native to Africa and Asia, where it is common in the tropics of Africa, the Sahelian and Sudanian ecozones, and the South Arabian Peninsula (TTPC 2010). Both old and young $D$. cinerea plants can produce many viable seeds annually which can survive for more than 5 years in the soil. This increases propagule pressure of the species. Its infructescence has a strong aroma, and this probably attracts animals to feed on the pods, facilitating seed dispersal. The species also forms impenetrable thickets that are difficult to eliminate due to high propagation capacity and propagule pressure of D. cinerea. Increased grazing and trampling pressure around boreholes was shown to cause a species-poor zone in the immediate vicinity of boreholes, followed by thickets with Acacia spp. and D. cinerea, transitional to tree savanna (Tolsma et al. 1987a).

Collection and grinding of $D$. cinerea fruits have been suggested as a management tool to control its encroachment (Mlambo et al. 2004). Chemical ways are often costly, and most herbicides are dangerous and have residual effects. Manual control is labour intensive and also less effective since new seedlings and coppicing replace the mechanically removed $D$. cinerea plants. The main aim of this study was to assess the effects of $D$. cinerea on herbaceous species diversity, richness, basal cover, litter cover, plant vigour and top hamper, determining the major herbaceous characteristics of invaded sites and the extent to which invaded and uninvaded sites differ. An analysis of the invasive capacity of $D$. cinerea on rangelands will contribute immensely to its management and control, hence achievement of the 2010 Convention on Biodiversity (CBD) target, which was also incorporated as a new target in the Millennium Development Goals (MDGs). 


\section{Materials and methods}

\section{Location}

Rangelands on Gokomere Farm located $18 \mathrm{~km}$ north of Masvingo town, and covering approximately 5800 hectares of land were studied. The farm lies in Natural Region IV (NR IV) of the Zimbabwean ecological classification system (Vincent and Thomas 1961). It is found at an altitude of $1163 \mathrm{~m}$ above sea level (19 $\left.57^{\prime} 45^{\prime \prime} \mathrm{S}, 30^{\circ} 46^{\prime} 34^{\prime \prime} \mathrm{E}\right)$. The farm is characterised by a few small kopjes, semi-vlei areas, and granite outcrops. Its soils are granite derived sandy-loams that are deficient in nitrogen, sulphur and phosphorous. Rainfall is unreliable both within and between seasons. Mean maximum and minimum temperatures of $21.8^{\circ} \mathrm{C}$ and $13.3^{\circ} \mathrm{C}$ are often experienced in October and June respectively. Hyparrhenia spp. was the main perennial cover, while Terminalia sericea and Combretum spp. were the main woody species.

\section{Plot demarcation, and herbaceous species and edaphic assessments}

A 2009 Google Earth Satellite Imagery of Gokomere Farm, followed by ground truthing was used to identify areas invaded by $D$. cinerea. Five $D$. cinerea patches were chosen using the nearest neighbour-plus-one-method. Three transects measuring $100 \mathrm{~m}$ each were laid down, the first one passing through the centre of each patch, and each of the other two at equi-distances from the middle and boundary of each patch. On each transect, two $10 \mathrm{~m} \times 10 \mathrm{~m}$ plots were systematically pegged on the ground. They were established at least $50 \mathrm{~m}$ from main roads and rivers to reduce road and river effects. Species presence/absence data and other herbaceous assessments were carried out in five $1 \mathrm{~m} \times 1 \mathrm{~m}$ quadrats established at the four corners and centre of each $10 \mathrm{~m} \times 10 \mathrm{~m}$ plot (Mueller-Dombois and Ellenberg 1974). For each quadrat, herbaceous cover, litter cover, top hamper, erosion and plant vigour were awarded numeric values ranging from 1-10 whereby the higher the attribute, the higher the value. Altitude and location of the sites were recorded using a Geographi-

cal Positioning System (GPS) unit. A soil auger was used to collect soil from the top $15 \mathrm{~cm}$ of the soil from each of the quadrats (Stohlgren et al. 1998). The soil samples from the same plot were thoroughly mixed and the composite sample was put in an air proof polythene bag. Analysis was done on N, P, K and pH at the Department of Soil Science, University of Zimbabwe.

\section{Data analysis}

SPSS Version 13.0 (2004) was used for one way analyses of variance (ANOVA) of the herbaceous and soil variables. PAST was used to calculate diversity indices. The herbaceous variables that were analysed were basal cover, litter cover, plant vigour and top 
hamper. Altitude, erosion and the edaphic variables $(\mathrm{pH}, \mathrm{N}, \mathrm{P}$ and $\mathrm{K}$ ) were included as explanatory variables. Multiple comparisons were done to test for significant differences among the plots. The relationships between the measured variables and the measured explanatory variables were explored using CANOCO for Windows (version 4). CANOCO was used to carry out Detrended Correspondence Analysis (DCA) and Redundancy Analysis (RCA) (ter Braak and Smilauer 1998). RCA was used to detect relationships using species data and the environmental variables measured. An unrestricted Monte-Carlo permutation test in CANOCO was used to test the statistical significance of the ordination (CANOCO, version 4.5 2002).

\section{Results}

\section{Herbaceous variables}

There was a total of 40 herbaceous species in the $D$. cinerea invaded and uninvaded sites. Invaded sites had 26 species while uninvaded sites had 32. The most common species in the invaded sites were Digitaria penzii, Cynodon dactylon and Eragrostis trichophora while in the uninvaded sites they were D. penzii, E. trichophora and Hyperthelia dissoluta (Table 1).

There were significant differences $\left(\mathrm{F}_{9,50}=9.375, \mathrm{P}<0.05\right)$ in basal cover among invaded and uninvaded sites. Invaded sites did not differ significantly $\left(\mathrm{F}_{9,50}=2.750, \mathrm{P}>0.05\right)$ in basal cover among themselves. However, the uninvaded sites showed significant differences $\left(\mathrm{F}_{9,50}=16.123, \mathrm{P}<0.05\right)$. Litter cover had significant differences among invaded and uninvaded sites $\left(\mathrm{F}_{9,50}=6.024 ; \mathrm{P}<0.05\right)$. Invaded sites were significantly different from each other $\left(\mathrm{F}_{9,50}=3.442, \mathrm{P}<0.05\right)$, as were the uninvaded sites $\left(\mathrm{F}_{9,50}=6.537, \mathrm{P}<0.05\right)$. Invaded sites recorded lower litter cover than uninvaded sites. Plant vigour in invaded sites was significantly different from that within uninvaded sites $\left(\mathrm{F}_{9,50}=5.796, \mathrm{P}<0.05\right)$. Both the invaded sites and uninvaded sites showed significant differences in plant vigour $\left(\mathrm{F}_{9,50}=8.037, \mathrm{P}<0.05\right.$ and $\mathrm{F}_{9,50}=4.605, \mathrm{P}<0.05$ respectively) among themselves. There were significant differences in top hamper among invaded and uninvaded sites

Table I. Herbaceous species variables among the invaded and uninvaded sites.

\begin{tabular}{c|c|c}
\hline Parameter & Invaded Site & Uninvaded Site \\
\hline Basal cover & $3.7^{\mathrm{a}}$ & $4.5^{\mathrm{b}}$ \\
\hline Litter cover & $1.5^{\mathrm{a}}$ & $2.1^{\mathrm{b}}$ \\
\hline Species richness & $2.9^{\mathrm{a}}$ & $3.5^{\mathrm{b}}$ \\
\hline Plant vigour & $2.9^{\mathrm{a}}$ & $3.4^{\mathrm{b}}$ \\
\hline Top hamper & $0.8^{\mathrm{a}}$ & $1.1^{\mathrm{b}}$ \\
\hline Shannon_H index & $2.58^{\mathrm{a}}$ & $2.85^{\mathrm{b}}$ \\
\hline Simpson_1-D index & $0.92^{\mathrm{a}}$ & $0.94^{\mathrm{b}}$ \\
\hline
\end{tabular}

Means in rows with different superscripts are significantly different $(\mathrm{P}<0.05)$ 
$\left(\mathrm{F}_{9,50}=3.264, \mathrm{P}<0.05\right)$. Invaded sites did not differ significantly $\left(\mathrm{F}_{9,50}=0.666, \mathrm{P}>0.05\right)$ in top hamper. Uninvaded sites had significant differences $\left(\mathrm{F}_{9,50}=6.959, \mathrm{P}<0.05\right)$. Species richness differed significantly $\left(\mathrm{F}_{9,50}=5.776, \mathrm{P}<0.05\right)$ among invaded and uninvaded sites. Invaded sites were not significantly different $\left(\mathrm{F}_{9,50}=1.052, \mathrm{P}>0.05\right)$ from each other in species richness. However, uninvaded sites had significant differences $\left(\mathrm{F}_{9,50}=7.113\right.$, $\mathrm{P}<0.05)$. Herbaceous species diversities also differed significantly $(\mathrm{P}<0.05)$ between invaded and uninvaded sites.

\section{Edaphic properties}

The $\mathrm{pH}$ values across invaded and uninvaded sites were significantly different $\left(\mathrm{F}_{9,50}=2.816, \mathrm{P}<0.05\right)$. Invaded sites had significant differences for $\mathrm{pH}$ among themselves $\left(\mathrm{F}_{9,50}=4.738, \mathrm{P}<0.05\right)$ unlike uninvaded sites $\left(\mathrm{F}_{9,50}=1.719, \mathrm{P}>0.05\right)$. There were significant differences $\left(\mathrm{F}_{9,50}=70.903, \mathrm{P}<0.05\right)$ for $\mathrm{K}$ between invaded and uninvaded sites. Both, invaded and uninvaded sites were significantly different from each other $\left(F_{9,50}=100.952, P<0.05 ; F_{9,50}=4.535, P<0.05\right)$. The recorded $P$ values showed significant differences $\left(\mathrm{F}_{9,50}=66.916, \mathrm{P}<0.05\right)$ between invaded and uninvaded values. Both invaded and uninvaded sites showed significant differences among themselves $\left(\mathrm{F}_{9,50}=51.018, \mathrm{P}<0.05\right.$ and $\mathrm{F}_{9,50}=24.872, \mathrm{P}<0.05$ respectively $)$. There were significant differences $\left(\mathrm{F}_{9,50}=3.980, \mathrm{P}<0.05\right)$ for the recorded $\mathrm{N}$ values between the invaded and uninvaded sites. Uninvaded sites significantly differed from each other $\left(\mathrm{F}_{9,50}=5.039\right.$, $\mathrm{P}<0.05)$ while invaded sites were not significantly different $\left(\mathrm{F}_{9,50}=2.735, \mathrm{P}>0.05\right)$. There were significant differences $\left(\mathrm{F}_{9,50}=6.193, \mathrm{P}<0.05\right)$ in altitude between the invaded and uninvaded sites. Invaded sites were significantly different $\left(\mathrm{F}_{9,50}=5.692, \mathrm{P}<0.05\right)$ from each other. Uninvaded sites also significantly differed $\left(\mathrm{F}_{9,50}=7.637, \mathrm{P}<0.05\right)$ from each other. Erosion significantly differed $\left(\mathrm{F}_{9,50}=3.303, \mathrm{P}<0.05\right)$ between invaded and uninvaded sites. Invaded sites had significant differences for erosion among themselves $\left(\mathrm{F}_{9,50}=4.420, \mathrm{P}<0.05\right)$, and so did uninvaded sites $\left(\mathrm{F}_{9,50}=3.182, \mathrm{P}<0.05\right)$.

\section{Herbaceous species-environmental relationships}

Of the $30 \mathrm{D}$. cinerea invaded plots (1-30) assessed for herbaceous species attributes, 26 were correlated with altitude, erosion, $\mathrm{pH}, \mathrm{P}, \mathrm{N}$ and $\mathrm{K}$ (Figure 1). Twenty five of the uninvaded plots (31-60), were negatively correlated with the measured environment variables. Invaded plots classified with these uninvaded sites were 6, 22, 23 and 25. They had low $\mathrm{K}$ values characteristic of the uninvaded sites studied, with the exception of sites 4 and 6. They all had lower $\mathrm{N}$ than the invaded plots (0.5-2.1 ppm compared to 3.3-5 $\mathrm{ppm}$ ). There was no clear pattern for $\mathrm{pH}$.

The species that were negatively correlated with these variables were Aristida spp., Pogonathria squarrosa, Rhynchelytrum repens, Panicum spp. and Digitaria penzii. K was positively correlated with Urochloa mozambicensis, Heteropogon contortus, Acanthosper- 


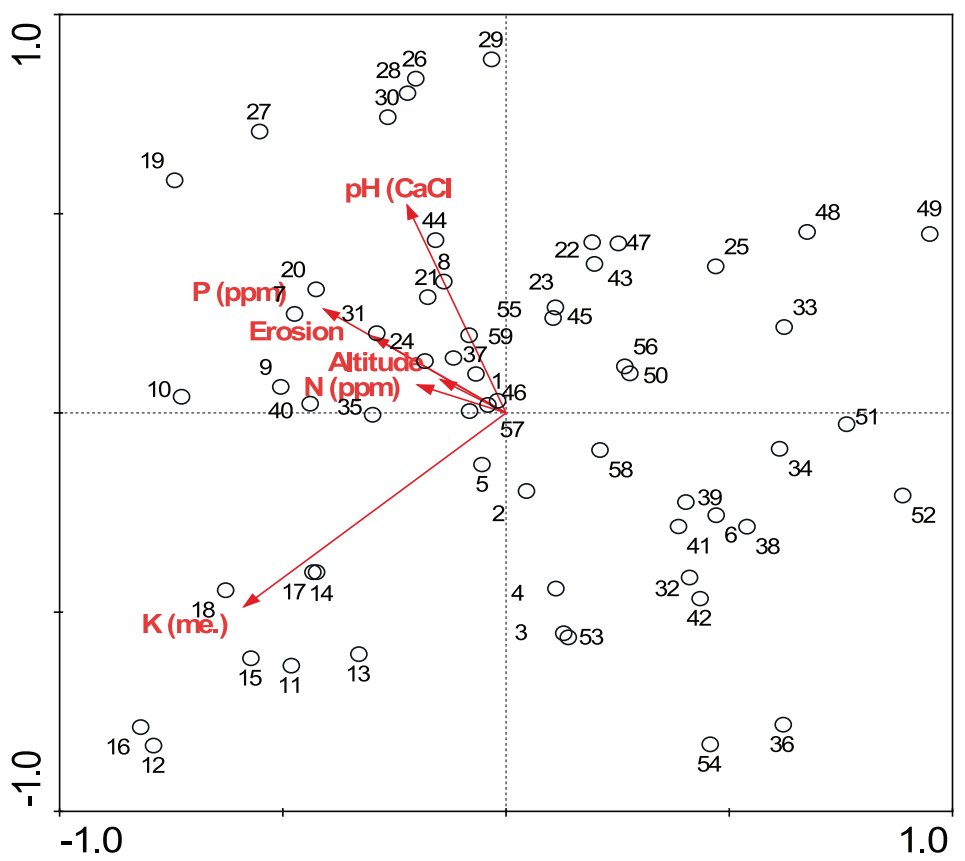

Figure I. A redundancy analysis plot based on herbaceous species presence absence data showing relationship between the environmental variables and the plots.

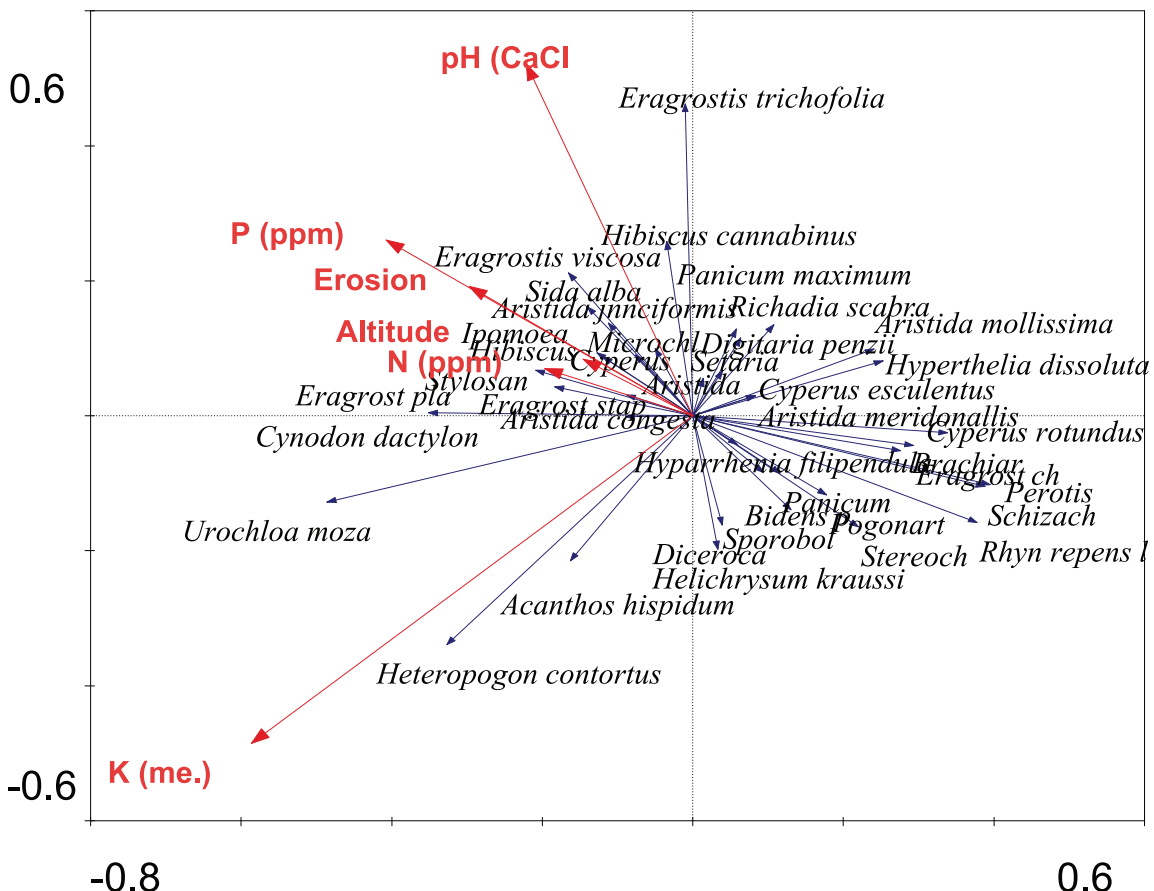

Figure 2. A redundancy analysis plot based on herbaceous species presence absence data showing relationship between the environmental variables and the species. 
mum hispidum etc. It was negatively correlated with Richadia scabra, Setaria palidifusca and Hyperthelia dissoluta (Fig. 2).

We show that $\mathrm{pH}$, erosion, $\mathrm{P}$, altitude and $\mathrm{N}$ influenced the abundance of species such as Hibiscus spp, Sida alba and Cynodon dactylon.

\section{Discussion}

\section{Herbaceous variables}

D. cinerea invasion has caused declines in herbaceous species richness. Competitive interactions are critical between woody plants and grass dominated layers in arid to semi-arid areas (Jacoby et al. 1982). D. cinerea may be competing with the native herbaceous species for resources such as light, nutrient and moisture. $C$. dactylon was one of the most abundant herbaceous species. It is very competitive, particularly in fertile soils, and only aggressive legumes are capable of forming an association with it (Harlan and de Wet 1969). This explains its occurrence in invaded sites. High litter deposition by a dominant plant species can also modify competition; suppress competing plants, and lower plant species richness (Xiong and Nilsson 1999). D. cinerea may have reduced herbaceous species richness through litter deposition or due to its vigorous growth characteristic, extensive and dense root system that is important in propagation and recruitment as compared to native species. Uninvaded sites also recorded higher species diversity indices (Shannon Weiner and Simpson's indices) than the invaded sites. Due to occurrence of certain species only unique to uninvaded sites in the absence of the suppressive nature of $D$. cinerea on other species, uninvaded sites had higher species richness than the invaded sites, hence higher Shannon-Weiner index.

In a study by Tolsma et al. (1987b), there was less than $10 \%$ ground cover by herbs and grasses in $D$. cinerea thickets, with the most frequent species being annual herbs like Boerhavia diffusa and weedy species such as A. hispidum, the latter of which was only found in invaded sites in the present study. Dense thickets such as those that are formed by $D$. cinerea can result in a decrease in carrying capacity through loss of grass cover caused by replacement and by competition for limited resources. In studying an invasive species of the genus Prosopis, although there were certain grasses that were adapted to shade conditions, there were others which were shade intolerant and were thus inhibited by competition with species of genus Prosopis (Jacoby et al. 1982). $P$. maximum grows better at $30 \%$ shade although yields are reduced by half at $50 \%$ shade (Harty et al. 1983). In the present study P. maximum was found in uninvaded sites which had lower canopy cover than the $D$. cinerea invaded sites, hence less shading. The reduced abundance of herbaceous species in this study could also be due to the negative impacts of increased $D$. cinerea canopy cover which may affect shadeintolerant species. Light deprivation may have affected basal cover, plant vigour and richness of herbaceous species noted in invaded sites as compared to uninvaded sites. The occurrence of $H$. contortus under the dense $D$. cinerea thickets is also in consistency with findings that $H$. contortus tolerate light shading, often dominating the understo- 
rey of Eucalyptus woodlands in tropical and subtropical Australia (Bhatt et al. 2006). While standing litter may protect seedlings from desiccation and high temperatures, it may also reduce light availability (Käller 2003) hence affect growth and production of other herbaceous species resulting in the observed lower herbaceous basal cover of invaded sites than that of uninvaded sites. Rapid root suckering of $D$. cinerea in propagation as well as high seed germination also make the specie a more successful invader with better plant vigour than the native herbaceous species.

In the present study there were significant differences in environmental variables between invaded and uninvaded sites. Invaded sites had higher soil N, K and P than uninvaded sites. Biological invaders change ecosystems as they differ from native species in resource acquisition and/or resource use efficiency. They may also alter the trophic structure of the area invaded, or the disturbance frequency and/or intensity (Vitousek 1990). The fluctuating resource availability theory states that plant species invasions are associated with increases in resources (Davis et al. 2000). D. cinerea is a nitrogen fixing shrub. The effect it has on soil could have been translated into herbaceous species composition. The decline in species richness means that native species are displaced by $D$. cinerea, resulting in a decrease in nutrient sequestration, hence increases in N, P and Kobserved in the invaded sites. Altitude also varied significantly among invaded sites. $D$. cinerea can occur on a wide range of altitude.

Eragrostis spp., Hibiscus spp., S. alba and U. mozambicensis were found in the D. cinerea invaded sites. These grasses are associated with disturbed land (Wild 1972). Disturbance is one of the major factors affecting species invasions (Davis et al. 2000). The Eragrostis spp. were positively correlated with erosion and negatively correlated with K. E. viscosa is an indicator of poor soil conditions such as is characteristic of eroded land (Wild 1972). E. chapelieri is also common on sandveld and it has poor forage value. Eroded soils are low in soil nutrients such as N, P and K. Erosion mostly affects the topsoil which provides the main nutrients needed by plants. $U$. mozambicensis is usually found in wooded grassland and deciduous bushland, or on disturbed sites where the soil is fertile (Burt et al. 1980). This explains the positive correlation of the species with potassium in D. cinerea invaded sites. Stylosanthes guianensis can extract $\mathrm{P}$ very efficiently from low $\mathrm{P}$ soils, but still responds to applications of $\mathrm{P}$, as well as $\mathrm{K}$, sulphur and calcium in soils with low levels of these nutrients (Chakraborty 2004). The species was positively correlated with K. C. dactylon was one of the most abundant herbaceous species. It grows on a wide range of soils, but best in relatively fertile, well-drained soils. It was correlated with N. It is very competitive, particularly in fertile soils.

The herbaceous species that were negatively correlated with the measured environmental variables were Aristida spp., P. maximum, Pogonarthria squarrosa, D. penzii, $H$. filipendula, $H$. dissoluta and $R$. repens among other species. P. maximum grows best in moist, well-drained soils just like $R$. repens, although some of its varieties are tolerant of lower fertility and poorer drainage (Harty et al. 1983, Wild 1972). The species was found in uninvaded sites which had lower canopy cover than the $D$. cinerea invaded sites, hence less shading. The correlation of $P$. squarrosa with uninvaded sites is in 
consistency with the findings of Wild (1972) who report that the species is a normal constituent of grassland on sandy soils. The Aristida spp. are drought resistant perennial grasses that grow in poor, gravely soils and also on clay soils.

\section{Conclusion}

Dichrostachys cinerea is a native invasive woody shrub or tree. Here, it adversely affected native herbaceous species plant vigour, basal cover and species richness. Reduced litter cover and top hamper were also observed in invaded sites. These observations can be attributed to the fast growth, propagation and propagule pressure that characterize $D$. cinerea, giving it a competitive advantage with respect to acquisition of light, nutrients and other resources. Therefore, these adverse effects on herbaceous species may, in the long term, reduce the carrying capacity of rangelands, making them even more susceptible to alien invaders. However, a long-term study may provide more information on the biology and invasive capacity of the species and on its impact on other vegetation and animal species. There is also need to find environmentally friendly and effective methods of controlling $D$. cinerea inorder to prevent its spread, hence adverse effects on herbaceous species.

\section{References}

Bhatt RK, Tiwari HS, Vandana S, Misra LP (2006) Photosynthesis and shade tolerance in tropical range grasses and legumes. Indian Journal of Plant Physiology 11: 172-177.

Burt RL, Sinclair DF, Harrison P, Pengelly BC, Williams WT (1980) Preliminary agronomic evaluation of some perennial Urochloa species over a range of environments. Australian Journal of Experimental Agriculture and Animal Husbandry 20: 439-446. doi: 10.1071/ EA9800439

Chakraborty S (Ed.) (2004) High-yielding anthracnose-resistant Stylosanthes for agricultural systems. ACIAR Monograph No 111. Australian Centre for International Agricultural Research, Canberra.

Davis MA, Grime JP, Thompson K (2000) Fluctuating resources in plant communities: A general theory of invasibility. Journal of Ecology 88: 528-534. doi: 10.1046/j.13652745.2000.00473.x

Harlan JR, de Wet JMJ (1969) Sources of variation in Cynodon dactylon (L.). Pers Crop Science 9: 774-778. doi: 10.2135/cropsci1969.0011183X000900060031x

Harty RL, Hopkinson JM, English BH, Alder J (1983) Germination, dormancy and longevity in stored seeds of Panicum maximum. Seed Science and Technology 11:341-351.

IPCC (2007) Impacts, adaptation and vulnerability. Contribution of Working Group II to the Fourth Assessment Report of the Intergovernmental Panel on Climate Change (IPCC). Cambridge University Press, Cambridge, UK.

Jacoby PW, Meadows CH, Foster MA (1982) Honey mesquite control and forage response in Crane County, Texas. Journal of Range Management 35: 424-426. doi: 10.2307/3898596 
Käller A (2003) Growth pattern and reproduction of woody vegetation in a semi-arid savanna in southern Botswana. Committee of Tropical Ecology, Minor Field Study, 86 pp.

Lonsdale WM (1999) Global patterns of plant invasions and the concept of invasibility. Ecology 80: 1522-1536. doi: 10.1890/0012-9658(1999)080[1522:GPOPIA]2.0.CO;2

Mlambo V, Smith T, Owen E, Mould FL, Sikosana JLN, Mueller-Harvey I (2004) Tanniniferous Dichrostachys cinerea fruits do not require detoxification for goat nutrition: In sacco and in vivo evaluations. Livestock Production Science 90(2-3): 135-144. doi: 10.1016/j. livprodsci.2004.03.006

Mueller-Dombois D, Ellenberg H (1974) Aims and Methods of Vegetation Ecology. John Wiley and Sons, New York, 547 pp.

Xiong S, Nilsson C (1999) The effects of plant litter on vegetation: A meta-analysis. Journal of Ecology 87: 984-994. doi: 10.1046/j.1365-2745.1999.00414.x

SCBD (Secretariat of the Convention on Biological Diversity) (2010) Global Biodiversity Outlook 3. Executive Summary, Montreal.

Stohlgren TJ, Bull KA, Otsuki Y, Villa CA, Lee M (1998) Riparian zones as havens for exotic plant species in the Central Grasslands. Plant Ecology 138: 113-125. doi: 10.1023/A:1009764909413

ter Braak CJF, Smilauer P (1998) Canoco Reference Manual and User's Guide to Canoco for Windows: Software for Canonical Community Ordination (version 4). Microcomputer Power, Ithaca.

Tolsma DJ, Ernst WHO, Verwey RA (1987a) Nutrients in soil and vegetation around two artificial waterpoints in eastern Botswana. Journal of Applied Ecology 24(3): 991-1000. doi: $10.2307 / 2403995$

Tolsma DJ, Ernst WHO, Verwey RA, Vooij R (1987b) Seasonal Variation of nutrient concentrations in a semi-arid Savanna ecosystem in Botswana, Journal of Ecology 75(3) : 755-770. doi: 10.2307/2260204

TTPC (Top Tropicals Plant Catalogue) (2010) Dichrostachys cinerea. www.toptropicals.com Vincent V, Thomas RG (1961) An Agricultural Survey of Southern Rhodesia. Part 1: AgroEcological Survey, Government Printers, Salisbury.

Vitousek PM (1990) Biological invasions and ecosystem processes: Towards an integration of population biology and ecosystem studies. Oikos 57: 7-13. doi: 10.2307/3565731

Wild H (1972) A Rhodesian botanical dictionary of African and English plant names. National Herbarium, Department of Research and Specialist Services. Ministry of Agriculture. Government Printer, Salisbury, Rhodesia. 